\title{
AKTIVITAS LARVASIDA EKSTRAK DAUN TUMBUHAN MARA TUNGGAL (Clausena excavata BURM.F) DAN DAUN ZODIA (Euodia ridleyi HOCHR) TERHADAP LARVA NYAMUK Culex SP.
}

\author{
Hadi Kuncoro \\ Laboratorium Farmaka Tropis, Fakultas Farmasi, Universitas Mulawarman, Samarinda \\ Email : kuncoro_hadi82@yahoo.com
}

\begin{abstract}
Has done research on larvacide activity Mara Tunggal leaves (Clausena excavata BURM.F) and Zodia leaves (Euodia ridleyi HOCHR) against larvae of the mosquito Culex sp. The study was conducted to see the massive concentration of Mara Tunggal leaves extracts and leaves Zodia can killed mosquito larvae Culex sp. The method used is a test using larvae of the mosquito Culex sp. By using various concentrations of extracts. From the results of research it is known that Mara Tunggal Leaf Extract and Leaf Zodia have activity against larvae of the mosquito Culex sp larvacide. With $L C_{50}$ values for the methanol extract of Mara Tunggal leaves $313.33 \mathrm{ppm}$ and methanol extract Zodia leaves is 5321,083 ppm.
\end{abstract}

Key Words : Clausena excavata BURM.F., Euodia ridleyi HOCHR., larvacide.

\begin{abstract}
ABSTRAK
Telah dilakukan penelitian aktivitas larvasida terhadap daun Mara Tunggal (Clausena excavata BURM.F) dan Daun Zodia (Euodia ridleyi HOCHR) terhadap Larva nyamuk Culex $s p$. Penelitian dilakukan untuk melihat besaran konsentrasi ekstrak dari daun Mara Tunggal dan Daun Zodia yang dapat membunuh larva nyamuk Culex sp. Metode yang digunakan adalah pengujian dengan menggunakan Larva nyamuk Culex $s p$. Dengan menggunakan berbagai konsentrasi Ekstrak. Dari hasil Penelitian diketahui bahwa Ekstrak Daun Mara Tunggal dan Daun Zodia memiliki aktivitas sebagai Larvasida terhadap Larva Nyamuk Culex sp. Dengan nilai $\mathrm{LC}_{50}$ untuk Ekstrak metanol daun Mara Tunggal 313,33 ppm dan Ekstrak metanol daun Zodia adalah 5321.083 ppm.
\end{abstract}

Kata Kunci : Clausena excavata BURM.F., Euodia ridleyi HOCHR., Larvasida

\section{PENDAHULUAN}

Nyamuk termasuk satu di antara jenis serangga yang memperoleh perhatian besar dalam kesehatan manusia, karena mempunyai potensi sebagai vektor dalam penularan suatu penyakit (Stocker, 2005). Beberapa nyamuk termasuk jenis antropofilik (lebih menyukai darah manusia) dan zoofilik (hanya menyerang hewan). Nyamuk jantan memperoleh makanan dari sari bunga, sedangkan nyamuk betina menggigit manusia dan binatang karena memerlukan darah dan protein untuk pembentukan telur (Gandahusada, 1998).

Tiga genus nyamuk yang menularkan penyakit ke manusia di Indonesia dengan prevalensi yang tinggi adalah genus 
Anopheles sp, Aedes sp, Culex sp L. Culex $s p$ merupakan nyamuk rumah yang mempunyai kebiasaan meletakkan telurnya di permukaan air secara bergerombol berbentuk seperti rakit. Nyamuk Culex $s p$ lebih menyukai meletakkan telurnya pada genangan air berpolutan tinggi, berkembang biak di air keruh dan lebih menyukai genangan air yang sudah lama daripada genangan air yang baru serta aktif menggigit di malam hari. Nyamuk Culex $s p$ merupakan golongan serangga penular (vektor). Nyamuk dari genus Culex $s p$ dapat menyebarkan penyakit Japanese Encephalitis (radang otak), Filariasis, dan West Nile Virus (WNV). Japanese Encephalitis (JE) merupakan penyakit radang otak menular bersifat zoonosis, menyerang hewan dan manusia, ditandai dengan demam, gejala syaraf dan kelainan reproduksi (WHO, 2005). Ada beberapa macam encephalitis diantaranya Japanese Encephalitis dan St Louis Encephalitis. Filariasis (penyakit gajah) adalah penyakit menular yang disebabkan oleh infeksi cacing filarial, yang hidup di saluran dan kelenjar limfa serta menyebabkan gejala akut atau kronik.

Tindakan pemberian insektisida pembasmi jentik (larvasida) merupakan tindakan preventif yang dilakukan untuk memberantas sarang nyamuk. Salah satu insektisida yang sering digunakan di Indonesia adalah abate (temephos). Temephos tidak digunakan secara oral. Karena kegunaannya yang terbatas, temephos tidak diharapkan keberadaanya di dalam air minum. Laporan resistensi larva Aedes aegypti terhadap Temephos sudah ditemukan di beberapa negara seperti Brazil, Bolivia, Argentina, Kuba, French, Polynesia, Karibia, dan Thailand. Selain itu juga telah dilaporkan resistensi larva Aedes aegypti terhadap temephos di Surabaya (Aradilla, 2009). Namun demikian, penggunaan bahan-bahan kimia yang berlebihan dan kurang hati-hati dapat menimbulkan bahaya yaitu sesak nafas apabila baunya menyengat dan alergi pada kulit, selain itu biasanya harganya mahal. Oleh karena itu perlu dicari alternatif lain yang lebih efektif dan lebih aman.

Tumbuhan Mara Tunggal (Clausena excavata Burm.f) merupakan tumbuhan yang memiliki kemampuan membunuh larva nyamuk. Hal ini didukung dengan adanya penelitian Cheng S.S (2008), minyak atsiri pada daun Mara Tunggal (Clausena excavata Burm.f) memiliki pengaruh terhadap mortalitas larva nyamuk Aedes aegypti didapatkan $\mathrm{LC}_{50}$ kurang dari 50 ppm dengan metode destilasi.

Tanaman zodia (Euodia ridleyi Hochr) dapat menjadi insektisida nabati karena banyak mengandung senyawa kimia salah satunya minyak yang terkandung di daun zodia yaitu linalool yang berfungsi sebagai pengusir nyamuk. Tanaman ini termasuk famili Rutaceae dan merupakan tanaman asli Indonesia. Masyarakat Papua terbiasa menggosok kulitnya dengan dedaunan zodia sebelum masuk ke hutan agar terlindung dari serangan serangga, khususnya nyamuk.

Berdasarkan pengalaman empiris masyarakat Papua tersebut, maka perlu dilakukan pengujian daun zodia yang berpotensi sebagai larvasida dengan menguji bioaktivitas ekstrak daun zodia terhadap larva nyamuk Culex sp.

\section{METODE}

\section{Bahan Penelitian}

Daun Tumbuhan Mara Tunggal dan Daun Zodia yang telah dikeringkan menjadi bentuk simplisia, Metanol, Larva Nyamuk Culex sp., tween 80 sebagai bahan yang 
Aktivitas Larvasida Ekstrak Daun Tumbuhan Mara Tunggal (Clausena excavata BURM.F) Dan Daun Zodia (Euodia ridleyi HOCHR) Terhadap Larva Nyamuk Culex SP.

membantu meningkatkan kelarutan ekstrak di dalam air, aluminium foil untuk menutup wadah atau hasil percobaan, dan aquadest.

\section{Alat Penelitian :}

Peralatan yang digunakan di dalam penelitian ini adalah seperangkat alat maserasi, rotary evaporator Vacuum, water bath, timbangan digital, mikro pipet, pipet tetes, pipet volume, erlenmeyer, gelas ukur, vial, deksikator.

\section{Uji Larvasida Ekstrak Daun Mara tunggal dan Daun Zodia}

Rancangan variasi konsentrasi ekstrak daun dan batang Mara Tunggal dibuat 5 variasi konsentrasi dengan 3 kali pengulangan (replikasi) untuk tiap perlakuan.

Tabel 1 Rancangan Uji larvasida Ekstrak daun Mara Tunggal dan Zodia

\begin{tabular}{ccccc}
\hline \multicolumn{5}{c}{ Variasi Konsentrasi Ekstrak Mara Tunggal/Zodia } \\
\hline $\mathrm{K}_{1} \mathrm{U}_{1}$ EMT & $\mathrm{K}_{2} \mathrm{U}_{1}$ EMT & $\mathrm{K}_{3} \mathrm{U}_{1}$ EMT & $\mathrm{K}_{4} \mathrm{U}_{1}$ EMT & $\mathrm{K}_{5} \mathrm{U}_{1}$ EMT \\
$\mathrm{K}_{1} \mathrm{U}_{2}$ EMT & $\mathrm{K}_{2} \mathrm{U}_{2}$ EMT & $\mathrm{K}_{3} \mathrm{U}_{2}$ EMT & $\mathrm{K}_{4} \mathrm{U}_{2}$ EMT & $\mathrm{K}_{5} \mathrm{U}_{2}$ EMT \\
$\mathrm{K}_{1} \mathrm{U}_{3}$ EMT & $\mathrm{K}_{2} \mathrm{U}_{3}$ EMT & $\mathrm{K}_{3} \mathrm{U}_{3}$ EMT & $\mathrm{K}_{4} \mathrm{U}_{3}$ EMT & $\mathrm{K}_{5} \mathrm{U}_{3}$ EMT \\
\hline$K_{\text {Keterangan }:} U_{1}$ EKP $=$ & Perlakuan Konsentrasi pertama Ulangan pertama Ekstrak Mara Tunggal /Zodia
\end{tabular}

Prosedur Pengujian Larvasida Terhadap Larva Nyamuk Culex sp.

\section{a) Penyiapan hewan uji}

Terhadap larva nyamuk Culex sp, disiapkan larva nyamuk Culex $s p$ dan dilakukan pemilihan secara visual untuk larva nyamuk yang akan digunakan, yaitu larva nyamuk instar III dengan ciri-ciri duri-duri dada mulai jelas dan corong pernafasan berwarna coklat kehitaman,

\section{b) Penentuan Seri Konsentrasi}

Pada penentuan seri konsentrasi dimana untuk dimulai dari $0-1250 \mathrm{ppm}$. Yang di mana 0 ppm sebagai kontrol atau pembanding. Penjabaran variasi seri konsentrasinya yaitu dimulai dari 100 ppm, 250 ppm, 500 ppm, 750 ppm dan 1000 ppm terhadap ekstrak metanol daun, ekstrak metanol batang dan fraksi etil asetat daun. Dan konsentrasi $50 \mathrm{ppm}, 75$ ppm, 100 ppm, 125 ppm, dan 150 ppm untuk fraksi n-heksana daun. Hal ini dilakukan pada uji pendahuluan, sehingga didapatkan batas konsentrasi yang efektif membunuh larva nyamuk Culex sp Terhadap larva Culex sp, pada ekstrak metanol daun konsentrasi 100 ppm sebagai batas bawah dan 500 ppm sebagai batas atas. Pada ekstrak metanol batang konsentrasi 100 ppm sebagai batas bawah dan $1000 \mathrm{ppm}$ sebagai batas atas. Pada fraksi n-heksana konsentrasi $25 \mathrm{ppm}$ sebagai batas bawah dan 150 ppm sebagai batas atas. Pada fraksi etil asetat konsentrasi 100 ppm sebagai batas bawah dan 1250 sebagai batas atas.

\section{c) Pengujian Toksisitas Larva Nyamuk Culex sp}

Disiapkan wadah pengujian. Dibuat masing-masing larutan stok 5000 ppm ekstrak metanol daun dan batang. Larutan stok $2500 \mathrm{ppm}$ untuk fraksi n-heksana daun dan larutan stok 10000 ppm untuk fraksi etil asetat daun. Dimasukkan larva 
Aktivitas Larvasida Ekstrak Daun Tumbuhan Mara Tunggal (Clausena excavata BURM.F) Dan Daun Zodia (Euodia ridleyi HOCHR) Terhadap Larva Nyamuk Culex SP.

nyamuk Culex sp sebanyak 10 ekor dimasukkan kedalam masing-masing vial kemudian dimasukkan ekstrak dan fraksi yang diuji terpisah dengan berbagai konsentrasi. Konsentrasi yang digunakan 100 ppm, 200 ppm, 300 ppm, 400 ppm, dan 500 ppm untuk ekstrak metanol daun. Konsentrasi 100 ppm, 250 ppm, 500 ppm, 750 ppm, dan 1000 ppm untuk ekstrak metanol batang. Konsentrasi 25 ppm, 20 ppm, 75 ppm, 100 ppm, 125 ppm dan 150 ppm untuk fraksi n-heksana daun. Dan konsentrasi 100 ppm, 250 ppm, 500 ppm, 750 ppm, 1000 ppm, 1250 ppm untuk fraksi etil asetat daun. Selanjutnya dicukupkan sampai volume $10 \mathrm{~mL}$ dengan aquades. Ditutup vial menggunakan aluminium foil dan ditusuk-tusuk dengan jarum agar udara dapat masuk. Diinkubasi selama 24 jam kemudian dicatat jumlah larva Culex sp yang mati.

\section{Analisa Data}

\section{Penentuan Aktivitas Larvasida Ekstrak}

Teknik analisis ini dilakukan secara deskriptif yaitu dengan membandingkan aktivitas larvsida (efek toksik) ekstrak daun mara tunggal dan zodia terhadap kontrol negatif (aquades). Aktivitas toksik dinyatakan dengan adanya kematian larva nyamuk Culex $s p$ sebagai parameter uji.

\section{Penentuan nilai Toksisitas $\left(\mathbf{L C}_{50}\right)$}

Pengambilan data dilaksanakan setelah mengerjakan uji aktivitas toksik ekstrak terhadap larva nyamuk Culex $s p$ secara terpisah. Data akhir uji toksisitas adalah nilai $\mathrm{LC}_{50}$. Untuk keperluan perhitungan disajikan tabel pengamatan. Perhitungan mortalitas larva nyamuk Culex $s p$ setelah perlakuan dengan berbagai konsentrasi ekstrak daun mara tunggal dan Daun Zodia

\section{HASIL DAN PEMBAHASAN}

\section{Aktivitas Larvasida Ekstrak Daun Mara Tunggal}

Aktivitas larvasida ekstrak daun Mara Tunggal terhadap larva nyamuk Culex $s p$ diketahui dari pengujian ekstrak Mara Tunggal yang memberikan daya bunuh terhadap larva nyamuk dengan membandingkan pada kontrol negatif (aquades) sebagai faktor koreksi terhadap aktivitas larvasida daun mara tunggal terhadap larva nyamuk Culex $s p$.

Perlakuan kontrol negatif adalah perlakuan yang tidak menggunakan sampel uji (ekstrak) tetapi tetap menggunakan bioindikator juga. Kontrol negatif berfungsi sebagai faktor koreksi dan pemastian bahwa bahan-bahan tambahan selain ekstrak uji tidak memiliki pengaruh atau kemampuan membunuh larva, sehingga dapat disimpulkan bahwa larva yang mati murni disebabkan oleh ekstrak daun Mara Tunggal.

\section{Uji Larvasida Ekstrak Metanol Daun Mara Tunggal}

Efek toksik ekstrak metanol daun Mara Tunggal terhadap larva Culex $s p$ dapat dilihat pada Tabel 2 dan Gambar 1.

Tabel 2 menunjukkan kontrol negatif (perlakuan yang tidak diberikan ekstrak metanol daun) kematian tidak memberikan efek toksik terhadap larva nyamuk Culex $s p$ disebabkan rata-rata kematian yang diperoleh yaitu 0 , sedangkan pada pengujian ekstrak metanol daun Mara Tunggal rata-rata kematian terkecil yaitu pada konsentrasi $100 \mathrm{ppm}$. Terlihat pada gambar gambar 1 bahwa kontrol negatif (uji yang tidak diberikan ekstrak metanol daun) tidak memberikan efek toksik terhadap larva nyamuk Culex sp. 
Aktivitas Larvasida Ekstrak Daun Tumbuhan Mara Tunggal (Clausena excavata BURM.F) Dan Daun Zodia (Euodia ridleyi HOCHR) Terhadap Larva Nyamuk Culex SP.

Konsentrasi terkecil 100 ppm telah menyebabkan kematian pada larva nyamuk dan semakin besar konsentrasi ekstrak metanol daun Mara Tunggal yang diberikan maka semakin meningkat pula rata-rata kematian larva nyamuk Culex $s p$.
Konsentrasi tertinggi yang menyebabkan mortalitas tertinggi yaitu pada konsentrasi $500 \mathrm{ppm}$. Hal ini menunjukkan bahwa ekstrak metanol daun Mara Tunggal dapat mematikan larva nyamuk Culex sp.

Tabel 2 Kematian Larva Culex sp terhadap Ekstrak Metanol Daun Mara Tunggal

\begin{tabular}{ccccccc}
\hline \multirow{2}{*}{ Replikasi } & Kontrol & \multicolumn{5}{c}{ Konsentrasi (ppm) } \\
\cline { 2 - 7 } & Negatif & 100 & 200 & 300 & 400 & 500 \\
\hline 1. & 0 & 1 & 3 & 4 & 6 & 9 \\
2. & 0 & 1 & 3 & 4 & 6 & 9 \\
3. & 0 & 1 & 3 & 4 & 6 & 9 \\
Jumlah & 0 & 3 & 9 & 12 & 18 & 27 \\
Rata-rata & 0 & 1 & 3 & 4 & 6 & 9 \\
\hline
\end{tabular}

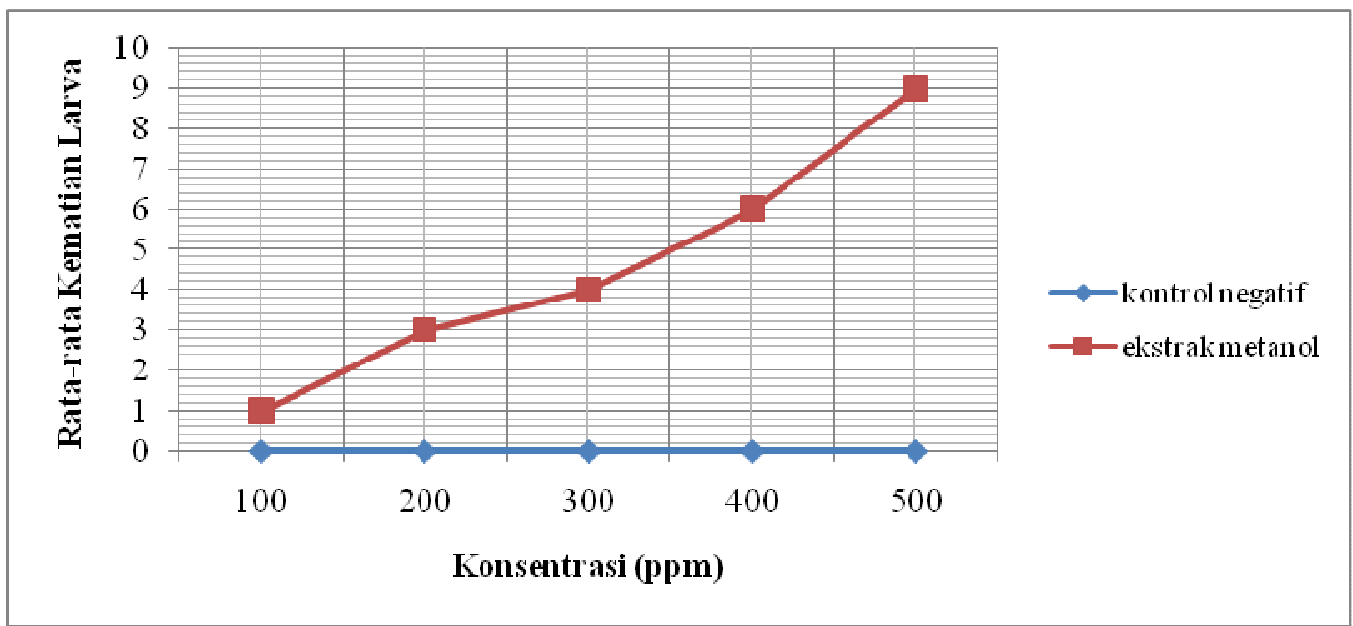

Gambar 1 Rata-rata kematian larva Culex sp terhadap Ekstrak Metanol Daun Mara Tunggal

Hasil pengujian toksisitas yang diperoleh dari ekstrak metanol daun Mara Tunggal terhadap larva Culex sp disajikan pada Tabel 3. Hasil dari Tabel 3 menunjukkan bahwa terjadi kematian $50 \%$ larva nyamuk Culex sp pada konsentrasi antara 200 ppm 300 ppm dan kematian $95 \%$ larva nyamuk Culex sp pada konsentrasi 400 ppm - 500 ppm.

Grafik pengaruh konsentrasi ekstrak kasar daun Mara Tungggal terhadap kematian larva Culex sp dapat dilihat di gambar 2.
Terlihat pada gambar 2 menunjukkan peningkatan konsentrasi ekstrak metanol daun Mara Tunggal yang berbanding lurus dengan jumlah kematian Culex $s p$ yang juga semakin meningkat. Hal ini dikarenakan semakin besar konsentrasi ekstrak dalam larutan ekstrak daun Mara Tunggal maka semakin banyak senyawa aktif yang masuk ke dalam tubuh larva nyamuk Culex sp sehingga kematian larva nyamuk juga semakin meningkat. 
Aktivitas Larvasida Ekstrak Daun Tumbuhan Mara Tunggal (Clausena excavata BURM.F) Dan Daun Zodia (Euodia ridleyi HOCHR) Terhadap Larva Nyamuk Culex SP.

Tabel 3. Persentase Mortalitas Ekstrak Metanol Daun Mara Tunggal terhadap Larva Culex sp

\begin{tabular}{cccccccc}
\hline \multirow{2}{*}{ Konsentrasi } & $\begin{array}{c}\text { Log } \\
\text { Konsentasi }\end{array}$ & \multicolumn{2}{c}{ Jumlah } & \multicolumn{2}{c}{ Terakumulasi } & $\begin{array}{c}\text { Rasio } \\
\text { mati : total }\end{array}$ & Mortalitas \\
\cline { 3 - 8 } & Mati & Hidup & $\begin{array}{c}\text { Mati } \\
(\mathrm{x})\end{array}$ & $\begin{array}{c}\text { Hidup } \\
(\mathrm{y})\end{array}$ & $\begin{array}{c}\text { Terakumulsi } \\
\mathrm{x}:(\mathrm{x}+\mathrm{y})\end{array}$ & $\begin{array}{c}\text { Rasio x } \\
100 \%\end{array}$ \\
\hline $100 \mathrm{ppm}$ & 2 & 3 & 27 & 3 & 79 & 0.037 & 3.7 \\
$200 \mathrm{ppm}$ & 2.301 & 9 & 21 & 12 & 52 & 0.188 & 18.8 \\
$300 \mathrm{ppm}$ & 2.477 & 14 & 16 & 26 & 31 & 0.456 & 45.6 \\
$400 \mathrm{ppm}$ & 2.602 & 18 & 12 & 44 & 15 & 0.746 & 74.6 \\
$500 \mathrm{ppm}$ & 2.699 & 27 & 3 & 71 & 3 & 0.959 & 95.9 \\
\hline
\end{tabular}

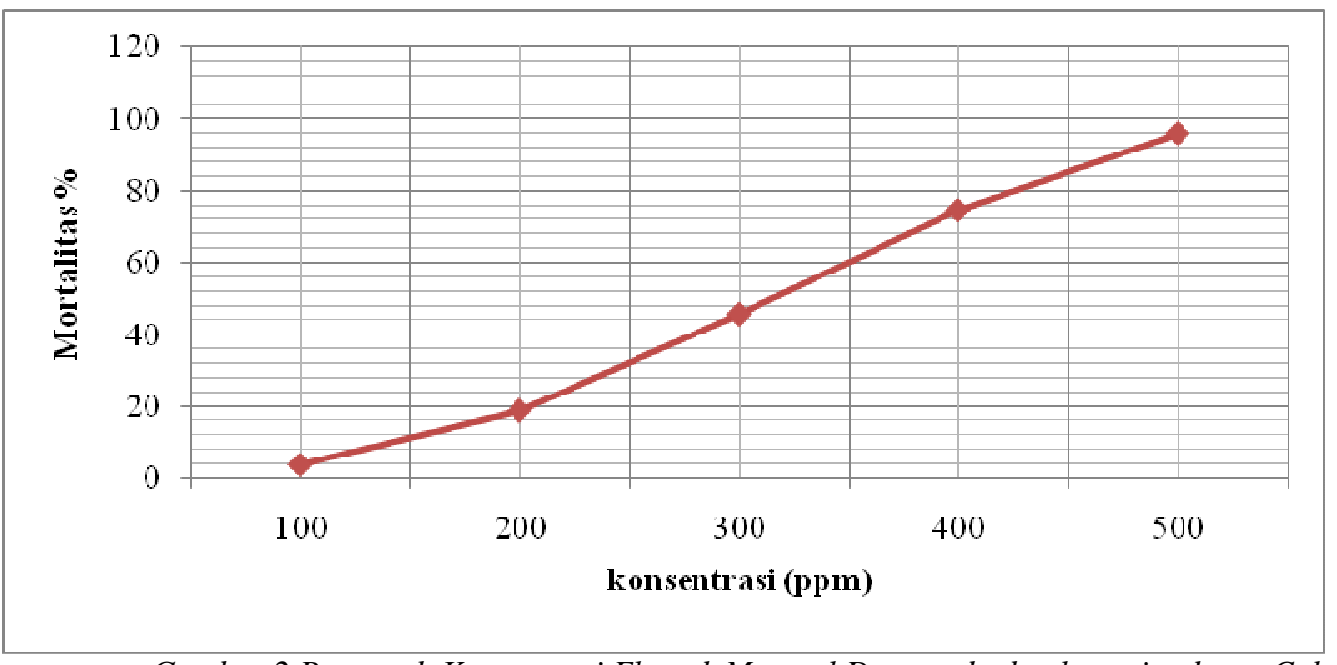

Gambar 2 Pengaruh Konsentrasi Ekstrak Metanol Daun terhadap kematian larva Culex sp

Berdasarkan perhitungan dengan menggunakan metode analisis Reed and Muench, ekstrak kasar daun Mara Tunggal terhadap larva nyamuk Culex $s p$ menunjukkan nilai LC $_{50}$ sebesar 313,33 ppm.

\section{Aktivitas Larvasida Ekstrak Daun Zodia}

Bioaktivitas ekstrak daun zodia dapat dilihat dari kemampuan ekstrak dalam memberikan aktivitas biologi terhadap larva nyamuk Culex sp dengan mengamati jumlah kematian larva uji. Kemampuan ekstrak dapat diukur dari besarnya konsentrasi sampel yang digunakan dalam mematikan larva nyamuk dengan menghitung nilai $\mathrm{LC}_{50}$ yang merupakan konsentrasi yang dapat menyebabkan kematian pada $50 \%$ hewan uji. Alasan penggunaan $\mathrm{LC}_{50}$ adalah karena konsentrasi ini merupakan batasan tengah dimana masih dapat memberikan efek terapi sekaligus efek toksik dari ekstrak uji. Bioindikator yang digunakan adalah larva nyamuk instar III-IV karena secara morfologi dan fisiologi lebih sempurna dibandingkan larva pada instar I-II sehingga memiliki sistem pertahanan yang lebih baik. Pengujian bioaktivitas menggunakan sampel uji dengan beberapa variasi konsentrasi disertai ulangan (replikasi) serta kontrol negatif yang berisi bioindikator dan media air tanpa penambahan ekstrak uji. 
Aktivitas Larvasida Ekstrak Daun Tumbuhan Mara Tunggal (Clausena excavata BURM.F) Dan Daun Zodia (Euodia ridleyi HOCHR) Terhadap Larva Nyamuk Culex SP.

Uji Bioaktivitas Ekstrak Kasar Daun Zodia terhadap Larva Nyamuk Culex sp

Ekstrak kasar hasil proses ekstraksi dengan metode maserasi dibuat larutan stok 10000 ppm (1\%) dan dibuat 6 variasi konsentrasi dengan 5 replikasi. Larva nyamuk yang digunakan tiap vial sebanyak 10 ekor. Pengamatan dan pencatatan dilakukan setelah 24 jam. Hail uji ekstrak kasar dapat dilihat pada tabel 4 .

Data pada tabel 4. menunjukkan bahwa kematian $50 \%$ hewan uji terjadi pada konsentrasi antara 4000-6000 ppm. Akumulasi hewan uji yang mati dan akumulasi hewan uji yang hidup dapat dilihat pada gambar 3 .

Tabel 4 Hasil Uji Bioaktivitas Ekstrak Kasar terhadap Larva Nyamuk Culex sp

\begin{tabular}{cccccccc}
\hline $\begin{array}{c}\text { Konsentrasi } \\
(\mathrm{ppm})\end{array}$ & $\begin{array}{c}\text { Log } \\
\text { Konsentrasi }\end{array}$ & \multicolumn{2}{c}{ Jumlah } & \multicolumn{2}{c}{ Terakumulasi } & Rasio mati : total & Mortalitas (\%) \\
\hline $1000 \mathrm{ppm}$ & 3 & 5 & 45 & 5 & 161 & 0.030 & Rati \\
$2000 \mathrm{ppm}$ & 3.3 & 12 & 38 & 17 & 116 & 0.128 & $3.0 \%$ \\
$4000 \mathrm{ppm}$ & 3.6 & 17 & 33 & 34 & 78 & 0.304 & $12.8 \%$ \\
$6000 \mathrm{ppm}$ & 3.8 & 29 & 21 & 63 & 45 & 0.583 & $30.4 \%$ \\
$8000 \mathrm{ppm}$ & 3.9 & 35 & 15 & 98 & 24 & 0.803 & $58.3 \%$ \\
$10000 \mathrm{ppm}$ & 4 & 41 & 9 & 139 & 9 & 0.939 & $80.3 \%$ \\
\hline
\end{tabular}

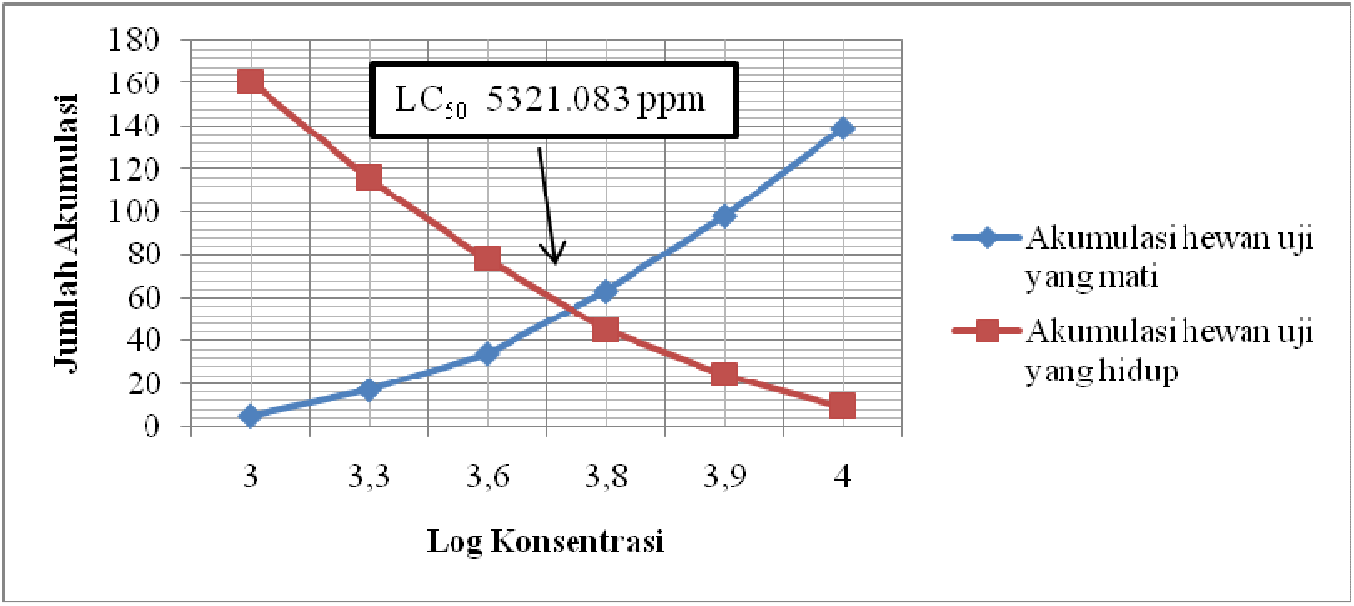

Gambar 3 Grafik Nilai $L C_{50}$ Ekstrak Kasar Daun Zodia

Gambar 3. menunjukkan bahwa terjadi peningkatan kematian hewan uji dengan bertambahnya konsentrasi ekstrak. Semakin besar konsentrasi ekstrak yang diberikan menunjukkan adanya peningkatan aktivitas dalam membunuh larva nyamuk karena semakin banyak kandungan senyawa atau zat aktif yang terdapat dalam ekstrak uji sehingga dapat diartikan semakin banyak senyawa aktif yang kontak dan masuk ke dalam tubuh larva nyamuk. Titik pertemuan grafik antara akumulasi kematian larva dengan akumulasi larva yang hidup merupakan estimasi nilai $\mathrm{LC}_{50}$. Berdasarkan hasil perhitungan Reed and Muench diperoleh nilai LC $_{50}$ esktrak kasar sebesar 5321.083 ppm dengan log konsentrasi 3.726. Nilai ini menunjukkan aktivitas ekstrak dalam membunuh larva nyamuk dimana pada konsentrasi tersebut, ekstrak dapat membunuh $50 \%$ hewan uji. 
Aktivitas Larvasida Ekstrak Daun Tumbuhan Mara Tunggal (Clausena excavata BURM.F) Dan Daun Zodia (Euodia ridleyi HOCHR) Terhadap Larva Nyamuk Culex SP.

\section{KESIMPULAN}

Dari Hasil Penelitian tersebut diketahui bahwa Ekstrak Metanol Daun Mara Tunggal dan Daun Zodia memiliki aktivitas sebagai larvasida terhadap larva nyamuk Culex $s p$. Nilai LC $_{50}$ Ekstrak metanol Daun Mara Tunggal adalah sebesar 313,33 ppm, dan Nilai LC $_{50}$ Ekstrak metanol Daun Zodia adalah sebesar 5321.083 ppm.

\section{DAFTAR PUSTAKA}

1. Agoes, G. 2007. Teknologi Bahan Alam. Penerbit ITB: Bandung

2. Ahmad, S.A. 2009. Ilmu Kimia dan Kegunaan Tumbuh-Tumbuhan Obat Indonesia. ITB: Bandung.

3. Aradilla, A.S. 2009. Uji Efektivitas Larvasida Ekstrak Ethanol Daun Mimba (Azadirachta indica) terhadap Larva Aedes aegypti. Universitas Diponegoro: Semarang.

4. Colegate, Steven M. dan Molyneux R.J. 1993. Bioactive Natural Products: Detection, Isolation and Structural Determination. CRC Press Inc: Florida.

5. Dewi, N.A. 2011. Potensi Ekstrak Daun Rambutan (Naphelium lappaceum L.) sebagai pembasmi larva nyamuk Culex pipiens. Skripsi. Fakultas Farmasi Universitas Mulawarman: Samarinda

6. Dinata, A. 2005. Tanaman Sebagai Pengusir Nyamuk. (http://www.pikiranrakyat.com/cetak/2005/0205/17/cakraw ala/penelitian01). Diakses pada tanggal 29 Februari 2012.

7. Dirjen POM. 2000. Parameter Standar Umum Ekstrak Tumbuhan Obat. Departemen Kesehatan Republik Indonesia: Jakarta.

8. Gandahusada, S., Henry D.I., Pribadi, W. 1998. Parasitologi Kedokteran Edisi Ketiga. Balai Penerbit FKUI: Jakarta
9. Gunawan, D. dan S. Mulyani. 2004. Ilmu Obat Alam (Farmakognosi) Jilid I. Penebar Swadaya: Jakarta.

10. Haeni, I. N. 2008. Uji Laboratorium Pemberian Insect Growth Regulator Pyriproxyfen terhadap Pertumbuhan dan Perkembangan Larva Aedes aegypti dan Aedes albopictus Asal Bantul. Daerah Istimewa Yogyakarta. Tesis. Universitas Gajah Mada: Yogyakarta.

11. Harjanto, I. 2004. Tanaman Harum Yang Dapat Mengusir Nyamuk. Diakses melalui http://rumahdme3.blogspot.com. tanggal 29 Februari 2012.

12. Hendayana, S. 2006. Kimia Pemisahan. Rosda: Bandung.

13. Henny, S. 2012. Uji Toksisitas Ekstrak Daun Dan Batang Mara Tunggal (Clausena excavata BURM.F) Terhadap Larva Nyamuk Aedes aegypti Dan Culex SP., Skripsi, Fakultas Farmasi Universitas Mulawarman, Samarinda.

14. Herbert, R.B. 1995. Bioaktivitas Metabolit Sekunder Edisi Kedua. Diterjemahkan oleh Bambang Srigandono. IKIP Press: Semarang.

15. Lenny, S. 2006. Senyawa Flavonoida, Fenil propanoida dan alkaloida. USU: Medan.

16. Soegijanto, S. 2004. Demam Berdarah Dengue. Airlangga University Press: Surabaya.

17. Stocker, Uwe dan Rene de Jong. 2005. Preventive Measures against Dengue Fever. Diakses melalui www.expat.or.id/medical/dengue.html. tanggal 29 Februari 2012.

18. Stojanovich, C.J. dan Scoot, H.G. 1965. Illustrated Key to Mosquitos of Vietnam. Department of Health Education and Welfare Public Health: USA. 
Aktivitas Larvasida Ekstrak Daun Tumbuhan Mara Tunggal (Clausena excavata BURM.F) Dan Daun Zodia (Euodia ridleyi HOCHR) Terhadap Larva Nyamuk Culex SP.

19. Teyler. V.E., L.R. Brady, J.E. Robbers. 1988. Pharmacognosy 9th Edition. Lea \& Febiger: Philadelphia.

20. Velayati, L. 2012, Kandungan Metabolit Sekunder Dan Daya Larvasida Ekstrak Daun Zodia (Euodia ridleyi HOCHR) Terhadap Larva Nyamuk Culex Sp., Skripsi, Fakultas Farmasi Universitas Mulawarman, Samarinda.

21. WHO. 2005. Panduan Lengkap Pencegahan dan Pengendalian Dengue dan Demam Berdarah Dengue. EGC; Jakarta
22. Wijiati, D. 2010. Uji Efektifivas Minyak Atsiri Bunga Kenanga (Cnangium odoratum Baill) Terhadap Daya Bunuh Larva Nyamuk Culex quinquefasciatus [Skripsi]. Fakultas Keguruan Pendidikan Universitas Muhammadiyah Surakarta : Surakarta

23. Yumita, A. 2011.Metabolit Sekunder dan Bioaktivitas terhadap Artemia Salina Leach Ekstrak Akar Singgah (Scurrula atropurpurea (Blume) Danser).Skripsi. Fakultas Farmasi Universitas Mulawarman: Samarinda. 